https://doi.org/10.18778/1509-877X.2020.04.01

\title{
INSTRUMENTY USZCZELNIAJĄCE SYSTEM PODATKOWY W PRAKTYCE ORZECZNICZEJ SĄDÓW ADMINISTRACYJNYCH
}

\begin{abstract}
Streszczenie. Podejmowane przez podatników - w tym przedsiębiorców - działania mające na celu minimalizowanie obciążeń podatkowych to zjawisko powszechne i w pewnym sensie zrozumiałe. $\mathrm{Z}$ tych względów wprowadzane zmiany $\mathrm{w}$ prawie podatkowym powinny $\mathrm{w}$ większym stopniu uwzględniać pojawiające się zagrożenia związane z uchylaniem się od opodatkowania. Nie budzi wątpliwości, że unikanie ciężaru podatkowego stoi w sprzeczności z celami opodatkowania - ta forma unikania opodatkowania powinna i może być zwalczana. Na ile trudnym zadaniem jest proces uszczelniania systemu podatkowego tak, aby spełnione zostały wymogi konstytucyjne, zgodność z prawem unijnym oraz zasady techniki prawodawczej, dowiodły wprowadzane $\mathrm{w}$ ostatnim okresie zmiany prawodawcze $\mathrm{w}$ tym zakresie. Potwierdziły to również problemy dotyczące stosowania w praktyce orzeczniczej sądów administracyjnych najważniejszych i mających znaczenie dla całego systemy poboru podatków rozwiązań wprowadzonych do ustawy Ordynacja podatkowa, tj. klauzuli ogólnej przeciwko unikaniu opodatkowania, systemu teleinformatycznego izby rozliczeniowej (STIR) oraz informacji o schematach podatkowych (MDR). Jak dowodzi analiza dotychczasowego orzecznictwa sądów administracyjnych na tle stosowania wybranych instrumentów uszczelniających pobór podatków w Polsce, przesłanki ich zastosowania powinny każdorazowo być rozpatrywane na gruncie konkretnych okoliczności faktycznych, nie tylko pod kątem zasad praworządności
\end{abstract}

* Prezes Izby Finansowej Naczelnego Sądu Administracyjnego, e-mail: jrudowski@nsa.gov.pl

(C) by the author, licensee Łódź University - Łódź University Press, Łódź, Poland. This article is an open access article distributed under the terms and conditions of the Creative Commons Attribution license CC-BY-NC-ND 4.0 (https://creativecommons.org/licenses/by-nc-nd/4.0/) 
i powszechności opodatkowania (art. 83-84 Konstytucji RP), ale także z uwzględnieniem zasady zaufania (art. 2 Konstytucji RP, art. $121 \$ 1$ o.p.), która w demokratycznym państwie prawnym oznacza m.in., że postępowanie powinno być prowadzone w zaufaniu do podatnika. $\mathrm{W}$ orzecznictwie podkreślono ponadto, że przy wprowadzaniu tego rodzaju dolegliwych dla podatników rozwiązań w sposób szczególny należy respektować zasadę proporcjonalności przy tworzeniu prawa.

Słowa kluczowe: podatki, prawo podatkowe, unikanie opodatkowania, uchylenie się od opodatkowania, klauzula ogólna, blokada rachunku bankowego, schematy podatkowe, sądy administracyjne

\section{Potrzeba UszcZelnienia systemu PodAtKowego}

Podejmowane przez podatników - w tym przedsiębiorców - działania mające na celu minimalizowanie obciążeń podatkowych to zjawisko powszechne i w pewnym sensie zrozumiałe. Zmniejszeniem ciężarów daninowych zainteresowane są praktycznie wszystkie podmioty obowiązane do ich ponoszenia. Negatywne zjawisko zwane unikaniem opodatkowania (tax avoidance) istnieje w każdym kraju o gospodarce rynkowej. Najczęściej realizuje się przez konstruowanie sztucznych, nadmiernie zawiłych konstrukcji prawnych, które np. dzielą gospodarczo jednorodne zdarzenie na etapy, aby wytworzyć wrażenie istnienia wielu odrębnych zdarzeń, czy też zawierają elementy wzajemnie się znoszące. Unikaniem opodatkowania są tego rodzaju działania, które nakierowane są na osiągnięcie korzyści podatkowych sprzecznych $\mathrm{z}$ intencją prawodawcy oraz celem i istotą regulacji podatkowych. Polegają one w szczególności na nadużywaniu preferencji podatkowych, nadużywaniu umów międzynarodowych, wykorzystywaniu "rajów podatkowych" i uzyskiwaniu przez to korzyści finansowej wynikającej z obniżenia ciężaru opodatkowania, względnie nawet uzyskania zwrotu podatku. W tym znaczeniu przez unikanie opodatkowania rozumie się zazwyczaj podejmowanie przez podatników legalnych działań zmierzających do wyeliminowania ciężaru opodatkowania lub jego ograniczenia w stosunku do poziomu uznawanego za adekwatny do danej sytuacji, rozpoznawanej z ekonomicznego, a nie formalnego punktu widzenia.

$\mathrm{Na}$ występowanie tego rodzaju niekorzystnych zjawisk zwrócił uwagę w wystąpieniu pokontrolnym Prezes Najwyższej Izby Kontroli po kontroli Ministerstwa Finansów z 12 stycznia 2015 r., P/14/013. W wystąpieniu tym zaprezentowano ocenę, zgodnie z którą w latach 2008-2013 obniżyła się relacja wpływów z podatku dochodowego od osób prawnych do produktu krajowego brutto: z 2,72\% w 2008 r. i 2,29\% w 2009 r. do 1,79\% w 2013 r. Było to wynikiem pogorszenia warunków prowadzenia działalności gospodarczej i obniżenia rentowności podmiotów gospodarczych. Spadek ten mógł być spowodowany także upowszechnieniem działań mających na celu unikanie 
lub uchylanie się od opodatkowania ${ }^{1}$. Z kolei w związku z przystąpieniem Polski do Unii Europejskiej nastąpiła zmiana otoczenia prawnego prowadzenia aktywności gospodarczej. Swobodny przepływ towarów i kapitału sprzyja procesom globalizacji. Procesy te mają swoje odbicie także w zmianach zachodzących w obszarze prawa podatkowego. $W$ tych warunkach prowadzenia działalności gospodarczej jedną z przyczyn międzynarodowego unikania opodatkowania stał się brak zharmonizowanego holdingowego prawa podatkowego w państwach członkowskich ${ }^{2}$. Głównym założeniem teorii rozdzielności podatkowej holdingów jest to, że spółki wchodzące w skład holdingu są opodatkowane jako odrębne podmioty. Przy tej konstrukcji zasad opodatkowania nie ma znaczenia fakt, że z ekonomicznego punktu widzenia spółki te stanowią jedność gospodarczą. Przy opodatkowaniu transakcji w ramach holdingu stosuje się zasady ogólne, tzn. traktuje się je tak, jakby były dokonywane pomiędzy podmiotami niezależnymi od siebie kapitałowo ${ }^{3}$.

Z tych względów wprowadzane zmiany w prawie podatkowym powinny $\mathrm{w}$ większym stopniu uwzględniać pojawiające się zagrożenia związane $\mathrm{z}$ uchylaniem się od opodatkowania. Na wystąpienie takich zagrożeń zwróciła uwagę Komisja Europejska w Zaleceniach z dnia 6 grudnia 2012 r. w sprawie agresywnego planowania podatkowego, C(2012)8806, które dotyczą podatków bezpośrednich. Jednym z zalecanych przez Komisję rozwiązań, mających na celu przeciwdziałanie praktykom agresywnego planowania podatkowego powodującym unikanie opodatkowania, jest przyjęcie przez państwa członkowskie zasady dotyczącej zwalczania nadużyć, dostosowanej do sytuacji krajowych, transgranicznych ograniczonych do Unii oraz do sytuacji, które dotyczą również państw trzecich.

Nie budzi wątpliwości, że unikanie ciężaru podatkowego stoi w sprzeczności z celami opodatkowania - ta forma unikania opodatkowania powinna i może być zwalczana. Przeciwdziałanie unikaniu opodatkowania może być zwalczane w różny sposób:

- po pierwsze - w drodze ustanowienia przez ustawodawcę norm prawnych zakazu unikania opodatkowania, tj. przez precyzyjne uregulowanie

1 Wystąpienie pokontrolne Prezesa Najwyższej Izby Kontroli po kontroli Ministerstwa Finansów z 12 stycznia 2015 r., P/14/013, s. 14, http://www.mf.gov.pl/c/document_library/ get_file?uuid=6627246f-40c7-425b-86f4-6524544e9089\&groupId=764034

2 Zob. D. Gajewski, Wpływ wybranych instrumentów prawnopodatkowych na politykę optymalizacji opodatkowania holdingów międzynarodowych, Warszawa 2012, s. 88-94.

${ }_{3}$ Zob. H. Litwińczuk, Prawo podatkowe przedsiębiorców, Warszawa 2003, s. 201-204. 
elementów konstrukcji podatku (wyeliminowanie luk umożliwiających podatnikowi wybór form prawnych, które pozwoliłyby na osiąganie zakładanego celu ekonomicznego i jednocześnie uniknięcie opodatkowania);

- po drugie - z wykorzystaniem kazuistycznych przepisów służących wyeliminowaniu konkretnych zachowań podatnika;

- po trzecie - za pomocą doktryn orzeczniczych kształtowanych w oderwaniu od konkretnych przepisów.

$\mathrm{Na}$ niepowodzenie skazana została zarówno próba wypracowania w latach dziewięćdziesiątych ubiegłego wieku przez sądy administracyjne pozanormatywnej koncepcji odwołującej się do zasady autonomii prawa podatkowego oraz reguł wypracowanych na tle stosowania art. 58 Kodeksu cywilnego ${ }^{4}$, jak i wprowadzenia w art. $24 \mathrm{~b}$ Ordynacji podatkowej ${ }^{5} \mathrm{z}$ dniem 1 stycznia 2003 r. klauzuli generalnej obejścia prawa podatkowego ${ }^{6}$. Po tych niepowodzeniach kolejne próby skoncentrowane zostały na wprowadzeniu kazuistycznych rozwiązań, które zmierzały do przynajmniej częściowego uszczelnienia systemu podatkowego przed najbardziej niepożądanymi zachowaniami podatników. Przykładem tego rodzaju rozwiązań jest wprowadzone uregulowanie przeciwko ściśle określonym zachowaniom podatnika podatku od towarów i usług w art. 88 ust. 3a pkt 4 lit. c ustawy o podatku od towarów i usług ${ }^{7}$ oraz bardziej uniwersalna klauzula w art. 199a o.p. Pierwszy z przepisów, art. 88 ust. 3 a pkt 4 lit. c u.p.t.u., odwołuje się zarówno do art. 58, jak i art. 83 k.c. Jest on rozumiany w aktualnym orzecznictwie sądowym w ten sposób, że użycie w tym wypadku spójnika „i” oznacza to, iż w jego myśl nie można obniżyć podatku należnego o podatek naliczony z faktur dokumentujących czynność nie tylko pozorną, ale również, na zasadzie art. $58 \$ 1$ i 2 k.c., sprzeczną z ustawą, mającą na celu obejście ustawy bądź sprzeczną z zasadami współżycia społecznego. Dlatego dla oceny zasadności zastosowania art. 88 ust. $3 a$ pkt 4 lit. c u.p.t.u. nie ma decydującego

${ }^{4}$ Ustawa z dnia 23 kwietnia 1964 r. - Kodeks cywilny (tekst jedn. Dz.U. z 2020 r., poz. 1740 ze zm.), dalej: k.c.

5 Ustawa z dnia 29 sierpnia 1997 r. - Ordynacja podatkowa (tekst jedn. Dz.U. z 2020 r., poz. 1325 ze zm.), dalej: o.p.

${ }^{6}$ Wyrok Naczelnego Sądu Administracyjnego (NSA) z dnia 24 listopada 2003 r., sygn. FSA 3/03; wyrok Trybunału Konstytucyjnego (TK) z dnia 11 maja 2004 r., sygn. K 4/03, wydany na wniosek Prezesa NSA oraz Rzecznika Praw Obywatelskich.

7 Ustawa z dnia 11 marca 2004 r. o podatku od towarów i usług (tekst jedn. Dz.U. z 2020 r., poz. 106), dalej: u.p.t.u. 
znaczenia prawidłowość zakwalifikowania przez organy podatkowe kwestionowanej czynności do art. 58 k.c. bądź art. 83 k.c. ${ }^{8}$ Z kolei art. 199a o.p. wprowadzony do ustawy z dniem 1 września 2005 r. ${ }^{9}$ uprawnia organy podatkowe do ustalania na gruncie prawa podatkowego rzeczywistej treści czynności cywilnoprawnej. Nie kwestionując skuteczności czynności pozornych, na gruncie prawa podatkowego nakazuje wywodzenie skutków podatkowych z czynności ukrytych. Jednak to, że stosownie do art. 199a $\$ 1$ o.p. organ podatkowy w trakcie ustalania treści czynności prawnej ma obowiązek badania zgodnego zamiaru stron i celu czynności, a nie tylko dosłownego brzmienia oświadczeń woli złożonych przez strony czynności, nie oznacza, iż jest to samodzielna podstawa do zakwestionowania skutków czynności prawnej dla celów podatkowych ${ }^{10}$.

Jak trudnym zadaniem jest proces uszczelniania systemu podatkowego tak, aby spełnione zostały wymogi konstytucyjne, zgodność z prawem wspólnotowym oraz zasady techniki prawodawczej, dowiodły również wprowadzane w ostatnim okresie zmiany prawodawcze w tym zakresie. Przede wszystkim wprowadzono z dniem 15 lipca 2016 r. klauzulę ogólną przeciwko unikaniu opodatkowania (art. 119a o.p.) oraz definicję nadużycia prawa w podatku VAT (art. 5 ust. 4 i 5 u.p.t.u.) ${ }^{11}$. Wprowadzono także wiele rozwiązań uszczelniających pobór VAT - odwrotne obciążenie w obrocie krajowym, solidarną odpowiedzialność nabywcy w związku z nabywaniem towarów wrażliwych, podzieloną płatność, dodatkową sankcję VAT, wykreślenie bez zawiadomienia z rejestru podatników VAT, jednolity plik kontrolny (JPK), system teleinformatyczny izby rozliczeniowej (STIR). Rozwiązania te mają ułatwić walkę z wyłudzeniami VAT. Rozwiązaniem systemowym jest też wprowadzenie obowiązku raportowania o schematach podatkowych (MDR).

W dalszej części wskazane zostaną problemy dotyczące stosowania $\mathrm{w}$ praktyce orzeczniczej sądów administracyjnych najważniejszych

8 Wyroki NSA z dnia: 25 lutego 2015 r., sygn. I FSK 93/14; 25 kwietnia 2017 r., sygn. I FSK 1226/15; 4 kwietnia 2018 r., sygn. I FSK 1029/16; 18 kwietnia 2019 r., sygn. I FSK 736/17; wszystkie wyroki opublikowano w CBOSA.

9 Ustawa z dnia 30 czerwca 2005 r. o zmianie ustawy - Ordynacja podatkowa oraz o zmianie niektórych innych ustaw (Dz.U. Nr 143, poz. 1199).

10 Wyroki NSA z dnia: 23 października 2020 r., sygn. II FSK 1710/17; 2 grudnia 2020 r., sygn. II FSK 2162/18; 21 stycznia 2021 r., sygn. II FSK 2516/18; wszystkie wyroki opublikowano w CBOSA.

11 Ustawa z dnia 13 maja 2016 r. o zmianie ustawy Ordynacja podatkowa oraz niektórych innych ustaw (Dz.U. z 2016 r., poz. 846). 
i mających znaczenie dla całego systemy poboru podatków rozwiązań wprowadzonych do ustawy Ordynacja podatkowa - klauzula ogólna przeciwko unikaniu opodatkowania (dział IIIa o.p.), system teleinformatyczny izby rozliczeniowej - STIR (dział IIIb o.p.) oraz informacje o schematach podatkowych - MDR (dział III rozdział 11a o.p.). Nie będzie to, z oczywistych względów, całościowe omówienie tych rozwiązań mających na celu uszczelnienie systemu podatkowego, ale jedynie wskazanie problemów orzeczniczych występujących na tym etapie w ich stosowaniu.

2. KlaUZULA PRZECIWKO UNIKANIU OPODATKOWANIA - ZAGADNIENIA SPORNE DOTYCZĄCE WYDAWANIA INTERPRETACJI INDYWIDUALNYCH ORAZ OPINII ZABEZPIECZAJĄCYCH

Klauzula ogólna przeciwko unikaniu opodatkowania została wprowadzona do polskiego systemu podatkowego z dniem 15 lipca 2016 r. ${ }^{12}$ Przepisy dotyczące klauzuli zostały umieszczone w nowo dodanym dziale IIIa Ordynacji podatkowej „Przeciwdziałanie unikaniu opodatkowania” (art. 119a$-119 z f)$. Charakterystycznymi cechami wprowadzonej w tych przepisach klauzuli jest znaczny stopień szczegółowości regulacji (32 artykuły) jako skutek wyroku Trybunału Konstytucyjnego (TK) z dnia 11 maja 2004 r., sygn. $\mathrm{K} 4 / 03^{13}$. Drugą cechą charakterystyczną jest dążenie do zgodność jej konstrukcji prawnej z wymogami dotyczącymi tego typu instytucji, wynikającymi z prawa unijnego, tj. z Dyrektywy Rady (UE) 2016/1164 z dnia 12 lipca 2016 r. ${ }^{14}$ Obecnie nie budzi wątpliwości, że wprowadzenie klauzuli ogólnej przeciwko unikaniu opodatkowania do polskiego systemu podatkowego było konieczne zarówno ze względu na potrzebę ochrony dochodów budżetowych, jak i wymogi stawiane państwom członkowskim przez prawo Unii Europejskiej. Klauzula ogólna przeciwko unikaniu opodatkowania wpływa na zapewnienie równego traktowania podatników i realizacji konstytucyjnej zasady równości opodatkowania nie tylko na płaszczyźnie stanowienia, ale także stosowania prawa ${ }^{15}$. Przy wykładni przepisów krajowych należy uwzględniać wskazania płynące z Dyrektywy Rady (UE)

12 Dz.U. z 2016 r., poz. 846 oraz Rządowy projekt ustawy o zmianie ustawy - Ordynacja podatkowa oraz niektórych innych ustaw, druk sejmowy 367/VIII kadencja.

13 OTK-A 2004/5/41; Dz.U. z 2004 r., Nr 122, poz. 1288.

14 Dz. Urz. UE L 193 z dnia 19 lipca 2016 r.

15 A. Olesińska, Klauzula ogólna przeciwko unikaniu opodatkowania, Toruń 2013, s. $17 \mathrm{i} \mathrm{n.}$ 
2016/1164 ustanawiającej przepisy mające na celu przeciwdziałanie praktykom unikania opodatkowania, które mają bezpośredni wpływ na funkcjonowanie rynku wewnętrznego. Dyrektywa bowiem nakładała w pkt 11 jej preambuły na państwa członkowskie obowiązek wprowadzenia do ich systemów podatkowych przepisów ogólnych przeciwko unikaniu opodatkowania, aby zwalczać nadużycia podatkowe, w odniesieniu do których nie zostały jeszcze przyjęte specjalnie ukierunkowane przepisy.

Przepisy ogólne przeciwko unikaniu opodatkowania w świetle Dyrektywy powinny mieć zastosowanie do uzgodnień, które nie są rzeczywiste. We wszystkich pozostałych przypadkach w świetle Dyrektywy podatnik powinien mieć swobodę wyboru takiej struktury podatkowej, która jest najbardziej efektywna z punktu widzenia prowadzonej przez niego działalności gospodarczej. Przy ocenie, czy dane uzgodnienie powinno być uznane za nierzeczywiste, zgodnie z Dyrektywą należy brać pod uwagę wszystkie ważne względy ekonomiczne, w tym działalność finansową. Artykuł 6 Dyrektywy określa treść ogólnej normy przeciwko unikaniu opodatkowania, którą państwa członkowskie powinny wprowadzić do swoich systemów podatkowych. Normatywny kształt klauzuli ogólnej przeciwko unikaniu opodatkowania, przyjęty w Ustawie z dnia 13 maja 2016 r. o zmianie ustawy - Ordynacja podatkowa oraz niektórych innych ustaw, realizował wymogi wynikające z powołanej Dyrektywy. Wprowadzenie do polskiego porządku prawnego klauzuli przeciwko unikaniu opodatkowania uporządkowało system prawa podatkowego, wyznaczając granice dopuszczalnej optymalizacji podatkowej oraz wzmacniając autonomię prawa podatkowego wobec prawa cywilnego.

Istotne zmiany w zakresie tych regulacji zostały wprowadzone $\mathrm{z}$ dniem 1 stycznia 2019 r. ${ }^{16}$ Za pozytywne rozwiązania należało uznać uporządkowanie powiązanych $\mathrm{z}$ klauzulą przepisów o indywidualnych interpretacjach podatkowych (nowe brzmienie art. $14 \mathrm{~b} \$ 2 \mathrm{a}$, art. $14 \$ 5 \mathrm{~b}$ i $5 \mathrm{c}$ oraz art. 14na o.p.), wprowadzenie regulacji umożliwiających cofnięcie skutków unikania opodatkowania, a w szczególności możliwość wycofania się ze schematów unikania opodatkowania dających korzyści podatkowe

${ }^{16}$ Ustawa z dnia 23 października 2018 r. o zmianie ustawy o podatku dochodowym od osób fizycznych, ustawy o podatku dochodowym od osób prawnych, ustawy - Ordynacja podatkowa oraz niektórych innych ustaw (Dz.U. poz. 2193) oraz Rządowy projekt ustawy o zmianie ustawy o podatku dochodowym od osób fizycznych, ustawy o podatku dochodowym od osób prawnych, ustawy - Ordynacja podatkowa oraz niektórych innych ustaw, druk sejmowy 2860/VIII kadencja. 
przez wiele lat. Zaletą tej drogi korygowania rozliczeń podatkowych będzie ograniczenie negatywnych skutków unikania opodatkowania, które zaistniałyby w przypadku wydania decyzji z zastosowaniem klauzuli przeciwko unikaniu opodatkowania (art. 119zfa i n. o.p. - odsetki od zaległości podatkowych, wymiar dodatkowego zobowiązania podatkowego). Wprowadzono również rozwiązania porządkujące postępowanie w sprawie zastosowania klauzuli, m.in. w zakresie wpływającym na poprawę ekonomiki postępowań przeciwko unikaniu opodatkowania, oraz doprecyzowano rolę Szefa Krajowej Administracji Skarbowej (KAS), jako organu podatkowego w zakresie wykonywania zadań dotyczących przeciwdziałania unikaniu opodatkowania. Dodano także rozwiązania zaostrzające przepisy, jako usprawiedliwienie wskazując zwiększenie funkcji prewencyjnej tych przepisów. Do tego rodzaju regulacji należy zaliczyć wprowadzenie dodatkowego zobowiązania podatkowego (art. 58a o.p.). Przede wszystkim jednak zmieniono definicję klauzuli ogólnej przeciwko unikaniu opodatkowania (art. 119a o.p.), obniżając dopuszczalny próg jej zastosowania, oraz zrezygnowano z licznych wyłączeń z jej zastosowania określonych w art. 119b o.p., w tym związanych z minimalną wielkością korzyści podatkowej.

Obecnie ukształtowane w ten sposób ramy prawne klauzuli ogólnej przeciwko unikaniu opodatkowania $\mathrm{z}$ warstwy rozważań teoretycznych przenoszone są na grunt wypowiedzi sądów administracyjnych. Wprawdzie do dziś nie została wydana w indywidualnej sprawie podlegająca kontroli sądowej decyzja przez Szefa KAS, to jednak do takich wypowiedzi dochodzi na gruncie regulacji art. $14 \mathrm{~b} \$ 5 \mathrm{~b}$ i $5 \mathrm{c}$ oraz art. 119w o.p. Rozstrzygnięcia w sprawie interpretacji indywidualnych oraz opinii zabezpieczających wyprzedzają rozstrzygnięcia w sprawie zastosowania klauzuli (art. 119a o.p.). Są więc poligonem doświadczalnym dla podatników (zainteresowanych), organów i sądów oraz mają niezaprzeczalny walor edukacyjny. W tym zakresie zapadło wiele wyroków sądów administracyjnych wskazujących interesujące aspekty nie tylko zastosowania przepisów procesowych, ale również samej normatywnej klauzuli przeciwko unikaniu opodatkowania. Równocześnie w związku z odmowami wszczęcia postępowania w sprawie wydania interpretacji indywidualnych na tle przedstawianych stanów faktycznych (zdarzeń przyszłych) ukształtowała się praktyka Szefa KAS publikowania ostrzeżeń podatkowych. Ponadto na tym etapie stosowania przepisów doszło do rozgraniczenia procedury wydawania interpretacji indywidualnych oraz opinii zabezpieczających w sprawie zastosowania klauzuli ogólnej przeciwko unikaniu opodatkowania (art. 119w o.p.). 
$\mathrm{W}$ procedurze interpretacji nie przeprowadza się postępowania dowodowego. Z kolei w procedurze wydawania opinii zabezpieczających tego rodzaju postępowanie $\mathrm{w}$ ograniczonym zakresie zostało dopuszczone (art. 119x $\$ 2$ oraz art. 119z o.p.). Zauważalna jest potrzeba zdefiniowania charakteru opinii zabezpieczających (art. 119w o.p.) i ich jednoznaczne odróżnienie od opinii, o których mowa w art. $14 \mathrm{~b} \$ 5 \mathrm{~b}$ i 5c o.p., wydawanych $\mathrm{w}$ postępowaniu interpretacyjnym oraz $\mathrm{z}$ art. 119h o.p. - opinie wydawane na potrzeby postępowania klauzulowego przez Radę do Spraw Przeciwdziałania Unikaniu Opodatkowania.

Już w pierwszym okresie po wejściu w życie tych regulacji pojawiły się istotne problemy w ich stosowaniu wymagające rozstrzygnięcia przez sądy administracyjne. Do tych problemów należały: dopuszczalność stosowania przy ocenie wniosków o interpretację indywidualną przez organy art. 14b $\$ 2$ a o.p. w kontekście klauzuli, jako przepisów adresowanych do organów podatkowych, określenie rodzaju rozstrzygnięcia, jakie wydaje organ interpretacyjny w przypadku negatywnej opinii Szefa KAS (art. 14b § 5c o.p.), charakter prawny ostrzeżeń publikowanych przez Szefa KAS, których źródłem są interpretacje indywidualne oraz odmowy wydania opinii zabezpieczających. W związku z wprowadzeniem do Ordynacji podatkowej przepisów o klauzuli przeciwko unikaniu opodatkowania (art. 119a-119zf) jednocześnie wprowadzone zostały w art. $14 \mathrm{~b} \$ 5 \mathrm{~b}$ i 5c o.p. rozwiązania tamujące wydawanie interpretacji indywidualnych przepisów prawa podatkowego w określonych przypadkach. W przepisach tych (art. 14na o.p.) przyjęto również, że ochrona prawna wynikająca z zastosowania się do otrzymanej interpretacji indywidualnej powinna być wyłączona wobec podmiotów, które świadomie układają stosunki prawne tak, aby unikać płacenia podatków. Jak wynika z uzasadnienia do projektu ustawy nowelizującej ${ }^{17}$, regulacja ta ma chronić przed nadużywaniem systemu interpretacji indywidualnych w zakresie unikania opodatkowania, na które to zagrożenie uwagę zwrócono w rezolucji Parlamentu Europejskiego z dnia 25 listopada 2015 r. w sprawie interpretacji prawa podatkowego i innych środków o podobnym charakterze lub skutkach $\left(2015 / 2066\right.$ (INI)) ${ }^{18}$.

Dla spraw unikania opodatkowania polski ustawodawca stworzył więc dedykowaną do ich specyfiki alternatywną procedurę opinii zabezpieczających. Określenie skutków podatkowych przyjęcia do przedmiotu opodatkowania czynności odpowiedniej - za czynność sztuczną (art. 119a \$2 o.p.)

17 Druk sejmowy nr 367 z 22 marca 2016 r./VIII kadencja, s. 41.

18 Dz. Urz. UE C-366/51 z dnia 27 października 2017 r. 
oraz określenie skutków podatkowych pominięcia czynności, której jedynym celem było osiągnięcie korzyści podatkowej (art. 119a $\$ 5$ o.p.) stanowi element postępowania podatkowego, uwzględniającego regulacje prawne klauzuli przeciwko unikaniu opodatkowania, które kończy się wydaniem decyzji podatkowej. Indywidualna interpretacja przepisów prawa podatkowego oraz opinia zabezpieczająca, która w istocie stanowi szczególną formę interpretacji, niewątpliwie nie są decyzjami podatkowymi. W obszarze ewentualnej konkurencji dwóch odrębnych postępowań: postępowania w przedmiocie wydania indywidualnej interpretacji przepisów prawa podatkowego i postępowania w przedmiocie wydania opinii zabezpieczającej, uzasadnione przypuszczenie, o którym mowa w art. 14b $\$ 5 \mathrm{~b}$ o.p., adekwatne jest zasadniczo do art. 119a $\$ 1$ o.p. Uzasadnione przypuszczenie możliwości zastosowania art. 119a $\$ 1$ o.p. implikuje bowiem spór prawny w zakresie wydania opinii zabezpieczającej lub wydania odmowy wydania opinii zabezpieczającej, których niewątpliwie nie wydaje się w postępowaniu w przedmiocie wydania indywidualnej interpretacji przepisów prawa podatkowego. Ewentualna ocena możliwości zastosowania art. 119a \$1 o.p. dokonana $\mathrm{w}$ postępowaniu o wydanie opinii zabezpieczającej nie stanowi decyzji podatkowej, może natomiast zostać potwierdzona w postępowaniu podatkowym, po zbadaniu przesłanek i wyłączenia odpowiedzialności podatkowej, wynikających z całości odpowiednich przepisów normujących klauzulę przeciwko unikaniu opodatkowania ${ }^{19}$.

$\mathrm{W}$ postępowaniu w przedmiocie wydania indywidualnej interpretacji przepisów prawa podatkowego, jak wskazuje się w orzecznictwie ${ }^{20} \mathrm{i}$ w piśmiennictwie $e^{21}$, nie stosuje się przepisów prawa materialnego regulujących określony podatek, ale jedynie ocenia zgodność z prawem dokonanej przez zainteresowanego wykładni przepisów prawa podatkowego. Interpretacja przepisów prawa podatkowego zaczyna działać w obszarze praw i obowiązków podmiotu materialnego prawa podatkowego, kiedy i jeżeli ten się do niej zastosuje, natomiast zastosowanie się do interpretacji nie jest składnikiem ich treści oraz wydawania i nie jest obowiązkiem zainteresowanego. Z tych względów złożenie wniosku o wydanie indywidualnej interpretacji przez podmiot zainteresowany co do zasady powoduje powstanie wyłącznie stosunku procesowego. $\mathrm{O}$ zaistnieniu stosunku o charakterze materialnym

19 Zob. wyrok NSA z dnia 21 marca 2018 r., sygn. II FSK 3819/17, CBOSA.

${ }^{20}$ Uchwała NSA z dnia 25 czerwca 2012 r., sygn. I FPS 4/12, CBOSA.

21 Por. R. Mastalski, Glosa do wyroku NSA z 1 grudnia 2011 r., I FSK 1565/11, „Orzecznictwo Sądów Polskich” 2012, nr 12, s. 119. 
można natomiast mówić dopiero w przypadku zastosowania się przez zainteresowanego do interpretacji indywidualnej. W takiej bowiem sytuacji pojawiają się wzajemne prawa i obowiązki organu podatkowego oraz adresata indywidualnej interpretacji, uregulowane w przepisach art. 14k-14na o.p. Podatnik zamierzający podjąć działania, co do których istnieje podejrzenie, że są podejmowane przede wszystkim w celu osiągnięcia korzyści podatkowej sprzecznej z przedmiotem i celem przepisu ustawy podatkowej, nie może zatem żądać wydania interpretacji indywidualnej zabezpieczającej te działania przed skutkami ewentualnej weryfikacji przez organy podatkowe. Ponadto zgodnie $\mathrm{z}$ art. 14 na pkt 1 o.p. przepisów art. $14 \mathrm{k}-14 \mathrm{n}$ nie stosuje się, jeżeli stan faktyczny lub zdarzenie przyszłe będące przedmiotem interpretacji indywidualnej stanowi element czynności będących przedmiotem decyzji wydanej z zastosowaniem art. 119a. To również podkreśla odrębność postępowań w sprawie wydania interpretacji indywidualnych oraz postępowania toczącego się na podstawie przepisów działu IIIa o.p. ${ }^{22}$

W orzecznictwie sądowym zaaprobowano praktykę organów, zgodnie z którą istnienie uzasadnionego przypuszczenia wydania decyzji z zastosowaniem art. 119a o.p. stanowi przeszkodę do wydania indywidualnej interpretacji tej wagi, że organ interpretacyjny powinien odmówić wszczęcia postępowania w sprawie jej wydania ${ }^{23}$. Wyjaśniono, że w stanie prawnym obowiązującym do 31 grudnia 2018 r. znajduje oparcie w art. 165a w zw. $\mathrm{z}$ art. 14h o.p. wydanie postanowienia o odmowie wszczęcia postępowania $\mathrm{w}$ sprawie wydania interpretacji indywidualnej w przypadku wystąpienia przesłanek, o których mowa w art. $14 \mathrm{~b} \S 5 \mathrm{~b}$ i 5 c tej ustawy. Organ interpretacyjny, odmawiając wydania interpretacji, musi jednak dysponować informacjami wynikającymi z przedstawionego we wniosku stanu faktycznego (zdarzenia przyszłego), na podstawie których może przyjąć, że możliwość wydania decyzji stwierdzającej unikanie opodatkowania jest oparta na konkretnych informacjach, a nie domysłach czy wyczuciu organu, względnie całkowitym pominięciu niektórych przesłanek wydania decyzji, o której mowa w art. 119a o.p. ${ }^{24}$ Warunkiem odmowy wszczęcia

22 Wyroki NSA z dnia: 28 czerwca 2017 r., sygn. II FSK 935/17; 19 grudnia 2017 r., sygn. II FSK 2877/17; oba wyroki opublikowano w CBOSA.

${ }^{23}$ Wyrok NSA z 27 września 2018 r., sygn. II FSK 290/18, „Orzecznictwo Naczelnego Sądu Administracyjnego i wojewódzkich sądów administracyjnych” 2020, nr 4, s. 46.

24 Wyroki NSA z dnia: 12 października 2018 r., sygn. II FSK 83/18; 2 grudnia 2020 r., sygn. II FSK 2927/18; 27 czerwca 2019 r., sygn. II FSK 2369/17; 27 czerwca 2019 r., sygn. II FSK 2373/17; 1 sierpnia 2019 r., sygn. II FSK 2707/17; wszystkie wyroki opublikowano w CBOSA. 
postępowania w przedmiocie wydania interpretacji indywidualnej na podstawie postanowień art. $14 \mathrm{~b} \$ 5 \mathrm{~b}$ o.p. jest przedstawienie przez organ przekonującej argumentacji, że w odniesieniu do choćby niektórych elementów stanu faktycznego lub zdarzenia przyszłego opisanych we wniosku o wydanie interpretacji może zaistnieć przesłanka wydania decyzji na podstawie art. 119a o.p. ${ }^{25}$ Podkreślenia wymaga jednak, iż w art. 14b $₫ 5 \mathrm{~b}$ o.p. jest mowa o „uzasadnionym przypuszczeniu”, że elementy danego stanu faktycznego lub zdarzenia przyszłego mogą być przedmiotem decyzji wydanej z zastosowaniem art. 119a o.p., przy czym „uzasadnione przypuszczenie” musi być oparte na obiektywnych racjach, poparte zbiorem argumentów, motywów, pobudek; coś ma swoje uzasadnienie, jeśli jest oparte na pewnej podstawie, coś tłumaczy się w określony sposób ${ }^{26}$. W skazanie $\mathrm{w}$ art. 14b $\$ 5$ b o.p., że odnośnie do wydania decyzji opartej na art. 119a tej ustawy stwierdzającej unikanie opodatkowania musi istnieć „uzasadnione przypuszczenie”, nie oznacza, o czym była już mowa, pewności wydania tejże decyzji. Pojęcie „uzasadnione przypuszczenie” odnosi się do podstawy faktycznej rozstrzygnięcia odmawiającego wydania interpretacji.

Sytuacja, w której udzielenie odpowiedzi stronie skarżącej we wnioskowanym zakresie ingerowałoby w odrębne postępowanie prawne prowadzone przez inny organ, stanowi wystarczającą przeszkodę, aby odmówić wszczęcia postępowania $\mathrm{w}$ sprawie $\mathrm{z}$ wniosku o wydanie interpretacji indywidualnej. Jednocześnie uzasadnione przypuszczenie możliwości zastosowania art. 119a $\$ 1$ o.p. implikuje spór prawny w zakresie wydania opinii zabezpieczającej lub odmowy wydania opinii zabezpieczającej, których niewątpliwie nie wydaje się w postępowaniu w przedmiocie wydania interpretacji indywidualnej przepisów prawa podatkowego. Podkreślono, że przepis art. 14b $\$ 5$ b o.p. odwołuje się tylko do art. 119a o.p., nie odsyła natomiast do badania wyłączeń z art. 119b tej ustawy. Zbadanie okoliczności z art. 119b o.p. wymaga, co do zasady, przeprowadzenia postępowania dowodowego, którego $\mathrm{w}$ postępowaniu dotyczącym wydania interpretacji się nie przeprowadza ${ }^{27}$.

25 Zob. prawomocne wyroki Wojewódzkiego Sądu Administracyjnego (WSA) w Gdańsku z dnia 1 sierpnia 2017 r., sygn. I SA/Gd 726/17, oraz WSA w Bydgoszczy z dnia 22 sierpnia 2017 r., sygn. I SA/Bd 551/17; oba wyroki opublikowano w CBOSA.

${ }_{26}$ Zob. Słownik języka polskiego, oprac. L. Drabik, A. Kubiak-Sokół, E. Sobol, L. Wiśniakowska, Warszawa 1996.

27 Wyroki NSA z dnia: 9 sierpnia 2019 r., sygn. II FSK 3118/17; 6 września 2019 r., sygn. II FSK 3354/17; 5 listopada 2019 r., sygn. II FSK 3804/17 i sygn. II FSK 3751/17; wszystkie wyroki opublikowano w CBOSA. 
Kolejne zagadnienie wyjaśniane w orzecznictwie sądów administracyjnych dotyczyło wystąpienia o opinię, o której mowa w art. 14b \$5c o.p. Sądy podkreśliły, że nie zależy ono od uznania organu interpretującego, jeżeli poweźmie on uzasadnione przypuszczenie, że elementy stanu faktycznego lub zdarzenia przyszłego mogą być przedmiotem decyzji z art. 119a o.p. Ustawodawca, nakazując zwrócenie się o taką opinię, nie unormował jej charakteru i nie wskazał wyraźnie na jej wiążący dla organu interpretującego charakter. Brak jednoznacznej wypowiedzi ustawodawcy w tym zakresie nie oznacza jednak, że opinia ta nie ma charakteru wiążącego dla organu wydającego interpretację. Wniosek taki można bowiem wyprowadzić z wykładni systemowej wewnętrznej i wykładni celowościo$w^{28}{ }^{28}$. Relacje pomiędzy opinią zabezpieczającą i interpretacją indywidualną są bowiem ukształtowane w taki sposób, że nie wydaje się interpretacji w zakresie tych elementów stanu faktycznego lub zdarzenia przyszłego, co do których istnieje uzasadnione przepuszczenie, że mogą być przedmiotem decyzji z zastosowaniem klauzuli przeciwko unikaniu opodatkowania. Skutki prawne opinii wydanej na podstawie art. $14 \mathrm{~b} \$ 5 \mathrm{c}$ o.p. sprowadzają się do tego, że jeżeli uprawniony organ do jej wydania potwierdzi w niej uzasadnione podejrzenie organu interpretującego, ten ostatni - związany nią - nie będzie mógł wydać interpretacji. Jeżeli natomiast opinia ta będzie negatywna, organ interpretujący nie będzie mógł odmówić jej wydania $\mathrm{z}$ powołaniem się na art. $14 \mathrm{~b} \S 5 \mathrm{~b}$ o.p. Odmowa wydania interpretacji nie pozbawia zainteresowanego ochrony. Może on w takiej sytuacji wystąpić o wydanie opinii zabezpieczającej, a odmowa jej wydania podlegać będzie kontroli sądu administracyjnego (art. $3 \$ 2$ pkt 4a ustawy Prawo o postępowaniu przed sądami administracyjnymi ${ }^{29} \mathrm{w}$ zw. $\mathrm{z}$ art. $119 \mathrm{y} \$ 3$ o.p.). Opinia zabezpieczająca, w przeciwieństwie do pisemnych interpretacji przepisów prawa podatkowego $\mathrm{w}$ indywidualnych sprawach, nie ogranicza się tylko do wykładni przepisów prawa podatkowego, ale ponadto ujmuje możliwość zastosowania klauzuli przeciwko unikaniu opodatkowania.

Naczelny Sąd Administracyjny, kontrolując zaskarżone odmowy wydania opinii zabezpieczającej, stwierdził, że instytucja opinii zabezpieczającej

${ }^{28}$ Wyroki NSA z dnia: 14 listopada 2019 r., sygn. II FSK 3967/17; 6 grudnia 2019 r., sygn. II FSK 51/18; 9 stycznia 2020 r., sygn. II FSK 289/18; 27 lutego 2020 r., sygn. II FSK 893/18; 5 marca 2020 r., sygn. II FSK 1014/18; 31 sierpnia 2020 r., sygn. II FSK 1517/18; wszystkie wyroki opublikowano w CBOSA.

${ }^{29}$ Ustawa $z$ dnia 30 sierpnia 2002 r. Prawo o postępowaniu przed sądami administracyjnymi (tekst jedn. Dz.U. z 2019 r., poz. 2325), dalej: p.p.s.a. 
została wprowadzona do Ordynacji podatkowej w celu zminimalizowania negatywnych dla podatników skutków wprowadzenia klauzuli przeciwko unikaniu opodatkowania. Umożliwia ona podatnikom uzyskanie stanowiska organów podatkowych co do skutków podatkowych planowanych lub dokonanych przedsięwzięć. Zawiera ocenę stanu faktycznego przedstawionego przez zainteresowanego we wniosku o wydanie opinii, w której organ rozstrzyga, czy opisany we wniosku stan faktyczny można zakwalifikować jako unikanie opodatkowania w rozumieniu art. 119a $\$ 1$ o.p. Skoro celem wniosku o wydanie opinii zabezpieczającej jest ustalenie, że do czynności opisanej w nim nie ma zastosowania art. 119a o.p., to tym samym wniosek zainteresowanego powinien zawierać wszystkie te informacje, które do oczekiwanej konstatacji (oceny skutków podatkowych czynności) mogą doprowadzić. Z tych względów wniosek o wydanie opinii zabezpieczającej, poza obligatoryjnymi elementami właściwymi dla każdego pisma procesowego wskazanymi w art. 119x $\$ 1$ o.p., powinien zawierać opis stanu faktycznego obejmujący elementy natury prawnej, ekonomicznej, gospodarczej i osobowej. Wydana na podstawie art. 119y $\$ 1$ o.p. opinia zabezpieczająca, w przeciwieństwie do pisemnych interpretacji przepisów prawa podatkowego $\mathrm{w}$ indywidualnych sprawach, nie ogranicza się tylko do wykładni przepisów prawa podatkowego, ale ponadto ujmuje możliwość zastosowania klauzuli przeciwko unikaniu opodatkowania, uwzględniając też zawarte w tej klauzuli aspekty gospodarcze planowanych działań oraz relacje korzyści ekonomicznych, gospodarczych i podatkowych. Negatywne stanowisko dla zainteresowanego polega na odmowie wydania opinii zabezpieczającej (art. 119y $\$ 2$ o.p.). W sytuacji negatywnej (odmownej) opinii szczególnego znaczenia nabiera jej uzasadnienie, które musi stanowić rzetelną informację dla wnioskodawcy, dlaczego w jego sprawie określone przepisy znajdują (bądź nie) zastosowanie, a także dlaczego wyrażony przez niego pogląd odmienny nie zasługuje na uwzględnienie. Odmowa wydania opinii zabezpieczającej obliguje zwłaszcza do wskazania okoliczności świadczących o tym, że do czynności ma zastosowanie art. 119a o.p. ${ }^{30} \mathrm{Za}$ niezwykle istotne uznano, że informacje o opiniach zabezpieczających lub odmowie ich wydania publikowane są niezwłocznie w Biuletynie Informacji Publicznej ministra właściwego do spraw finansów publicznych (od 1 stycznia 2019 r. kwestię tę reguluje art. 119zda o.p., poprzednio publikowana była treść opinii lub odmów, po usunięciu danych identyfikujących podmioty, których dotyczyła, stosownie do art. 14i $₫ 3$

30 Wyroki NSA z dnia: 31 stycznia 2019 r., sygn. II FSK 3242/18; 8 lipca 2020 r., sygn. II FSK 2797/19; oba wyroki opublikowano w CBOSA. 
w zw. z art. 119zf o.p.). Pozwala to zainteresowanym uzyskać informację co do możliwych skutków planowanych lub podjętych przez nich działań także bez potrzeby występowania o opinię zabezpieczającą.

Ponadto ze względu na podnoszone zarzuty, oceniając odmowę wydania opinii zabezpieczającej, NSA wyraził pogląd, że jeżeli podatnik z kilku możliwych, legalnych sposobów działania prowadzących do osiągnięcia celu ekonomicznego lub gospodarczego wybiera taki, który nie jest sposobem typowym, zazwyczaj wykorzystywanym do osiągnięcia planowanego celu, ale który jako jedyny pozwala na podstawie literalnego brzmienia ustawy na osiągnięcie korzyści podatkowej sprzecznej z celem i przedmiotem ustawy, to taki sposób działania uznać należy za sztuczny w rozumieniu art. $119 \mathrm{c} \$ 1$ o.p. ${ }^{31}$

3. Blokada RACHUNKu PODMiotu KWALIFIKOWANEGo - OCENA SĄDOWA ZASAD STOSOWANIA PRZEZ UPRAWNIONE ORGANY

Działania legislacyjne ukierunkowane na uszczelnienie systemu podatkowego służą zagwarantowaniu bezpieczeństwa ekonomicznego państwa i dochodów budżetowych. STIR, czyli System Teleinformatyczny Izby Rozliczeniowej, to zespół algorytmów analizujących dostarczane obowiązkowo przez banki i SKOK-i dane finansowe dotyczące przedsiębiorców. System ma wychwytywać anomalie, które mogą mieć znamiona czynności zmierzających do wyłudzania VAT, w tym także polegające np. na wystawianiu pustych faktur. Ma także pomóc $\mathrm{w}$ walce $\mathrm{z}$ karuzelami VAT-owskimi i zawczasu reagować, co może w znacznej części ułatwić wychwytywanie oszustw podatkowych. Dla typowego, rzetelnego podatnika działanie STIR nie powinno być zasadniczo widoczne. System ukierunkowany jest bowiem na analitykę na poziomie bankowym i ma na celu identyfikację transakcji, które odznaczają się cechami przynależnymi czynnościom o charakterze wyłudzeniowym. Klarowny przykład zastosowania STIR to sytuacja dokonywania kilkunastu przelewów i przelewów zwrotnych między tymi samymi podmiotami w krótkim okresie. Podatnicy niedokonujący takich transakcji nie powinni obawiać się wdrożenia STIR. Szef KAS codziennie otrzymuje za pośrednictwem STIR informacje o rachunkach podmiotów kwalifikowanych, prowadzonych przez banki i spółdzielcze

31 Wyrok NSA z dnia 8 lipca 2019 r., sygn. II FSK 135/19, CBOSA. 
kasy oszczędnościowo-kredytowe, oraz transakcjach na tych rachunkach w celu dokonania analizy ryzyka wystąpienia wyłudzenia skarbowego ${ }^{32}$.

Przepisy ustanawiające omawiany system zostały wprowadzone do polskiego porządku prawnego Ustawą z dnia 24 listopada 2017 r. o zmianie niektórych ustaw w celu przeciwdziałania wykorzystywaniu sektora finansowego do wyłudzeń skarbowych ${ }^{33}$. W akcie tym znowelizowano Ustawę z dnia 29 sierpnia 1997 r. - Ordynacja podatkowa, wprowadzając do niej nowy dział IIIb „Przeciwdziałanie wykorzystywaniu sektora finansowego do wyłudzeń skarbowych”. W przepisach tych (art. 119zv-119zze o.p.) uregulowano m.in. mechanizm blokady rachunku podmiotu kwalifikowanego na żądanie Szefa KAS oraz związane $\mathrm{z}$ tym konsekwencje prawne i procesowe. Najważniejszym celem ustawy było ograniczenie luki w podatku VAT spowodowanej wyłudzeniami. Projekt wprowadza system eliminujący z obrotu gospodarczego podstawione firmy oszukujące uczciwych przedsiębiorców i przez to wzmacnia bezpieczeństwo podatników VAT $\mathrm{w}$ obrocie gospodarczym ${ }^{34}$. Już na etapie prac nad wprowadzeniem tych rozwiązań podnoszona była problematyka zakresu kontroli sądowej blokad rachunku bankowego podmiotów kwalifikowanych. Podkreślano, że sąd może zbadać treść akt ilustrujących ustalenia programu, nie ma jednak narzędzi prawnych do badania poprawności budowy algorytmu ani wiedzy o specyfice jego działania. $Z$ tego względu kontrola zgodności z prawem tego rodzaju postanowień może być iluzoryczna, jeżeli nie niemożliwa ${ }^{35}$.

W pierwszym okresie po wprowadzeniu tych regulacji kontrola sądowa ukierunkowana została na stosowanie w indywidualnych sprawach przez Szefa KAS art. 119zv o.p. dotyczącego żądania blokady rachunku podmiotu kwalifikowanego na okres nie dłuższy niż 72 godziny, art. 119zw o.p. dopuszczającego przedłużenia takiej blokady na czas oznaczony nie dłuższy

32 Objaśnienie podatkowe Ministra Finansów z dnia 6 kwietnia 2018 r. w sprawie stosowania przepisów wprowadzonych ustawą z dnia 24 listopada 2017 r. o zmianie niektórych ustaw w celu przeciwdziałania wykorzystywaniu sektora finansowego do wyłudzeń skarbowych, https://mf-arch2.mf.gov.pl/c/document_library/get_file?uuid=db9ddeb2-98c74fdf-bd91-ea3a288c11c6\&groupId=764034

33 Dz.U. z 2017 r. poz. 2491, dalej: ustawa STIR.

${ }^{34}$ Uzasadnienie rządowego projektu ustawy o zmianie niektórych ustaw w celu przeciwdziałania wykorzystywaniu sektora finansowego do wyłudzeń skarbowych, druk sejmowy nr 1880/VIII kadencja.

35 Zob. M. Szubiakowski, Problemy proceduralne blokady rachunku bankowego w celu przeciwdziałania wytudzeniom skarbowym, „Zeszyty Naukowe Sądownictwa Administracyjnego" 2018, nr 3(78), s. 53-54. 
niż 3 miesiące oraz przesłanek zastosowania obu tych przepisów. Szczególne zastrzeżenia budziło zniesienie od 22 sierpnia 2018 r. możliwości zaskarżania krótkotrwałej blokady rachunku (do 72 godzin) w formie zażalenia, a następnie skargi do sądu administracyjnego ${ }^{36}$. Dla przypomnienia, w stanie prawnym obowiązującym przed 22 sierpnia 2018 r. Szef KAS wydawał w tym celu postanowienie o blokadzie rachunku, na tak wydane postanowienie przysługiwał zaś wniosek o ponowne rozpatrzenie sprawy, a następnie skarga do sądu administracyjnego. Podmiot kwalifikowany zachował możliwość zaskarżenia postanowienia o przedłużeniu blokady (na czas oznaczony nie dłuższy niż 3 miesiące), co wynika z niezmienionego w tym zakresie art. $119 z z b \$ 1$ o.p. Orzecznictwo sądów administracyjnych odnoszące się do dopuszczalności pośredniej kontroli blokady rachunku bankowego na okres do 72 godzin (blokada krótka) w początkowym okresie nie było jednoznaczne ${ }^{37}$. Wyjaśniono, że postępowanie w sprawie krótkiej (72-godzinnej) blokady i postępowanie w sprawie przedłużenia blokady, jakkolwiek muszą się zazębiać czasowo mocą art. 119zw $\$ 4$ o.p., to jednak operują zupełnie innymi przesłankami, a zaskarżalność przewidziana jest tylko w tej drugiej procedurze.

Od tego poglądu NSA odstąpił w kolejnych wyrokach kształtujących obecnie jednolitą linię orzeczniczą ${ }^{38}$. Podkreślono, że zgodna z konstytucyjnymi zasadami wykładnia i analiza treści art. 119zv $\$ 1$ i art. 119zw $\$ 1$ o.p. prowadzi do wniosku, iż przesłanki tzw. krótkiej blokady rachunku podlegają kontroli sądowoadministracyjnej na podstawie art. $134 \$ 1$ w zw. z art. 135 p.p.s.a. w przypadku zaskarżenia postanowienia Szefa KAS w przedmiocie przedłużenia tejże blokady na czas oznaczony. W ocenie NSA brak sądowej kontroli „decyzji” Szefa KAS w przedmiocie krótkotrwałej blokady rachunku podmiotu kwalifikowanego (do 72 godzin) budzi wątpliwości co do konstytucyjności takiego rozwiązania. Należy przede wszystkim rozważyć, na ile wyłączenie możliwości wniesienia skutecznego zaskarżenia do sądu tego typu aktów administracji da się pogodzić z art. 45,

36 Ustawa z dnia 5 lipca 2018 r. o zmianie ustawy - Ordynacja podatkowa oraz niektórych innych ustaw (Dz.U. z 2018 r., poz. 1499).

37 Wyroki NSA z dnia: 3 marca 2020 r., sygn. I FSK 1425/19; 26 lutego 2020 r., sygn. I FSK 1719/19; oba wyroki opublikowano w CBOSA.

38 Wyroki NSA z dnia: 3 marca 2020 r., sygn. I FSK 1888/19; 27 kwietnia 2020 r., sygn. FSK 335/20; 27 kwietnia 2020 r., sygn. I FSK 491/20; wszystkie wyroki opublikowano w CBOSA. 
art. 77 ust. 2 i art. 78 Konstytucji Rzeczypospolitej ${ }^{39}$. Przyjmuje się, że konstytucyjne prawo do sądu obejmuje zarówno prawo do wymiaru sprawiedliwości, czyli merytorycznego rozstrzygnięcia w sprawach z zakresu praw jednostki, jak i prawo do sądowej kontroli aktów, które godzą w konstytucyjne prawa i wolności jednostki. W tym ostatnim przypadku sąd realizuje czynności z zakresu ochrony prawnej, chroniąc jednostkę przed arbitralnością działań podmiotu sprawującego władztwo publiczne. Prawo do sądu oznacza dla ustawodawcy obowiązek ustanowienia regulacji prawnej, która zapewni rozpatrzenie sprawy przez sąd na żądanie zainteresowanego. Odwołując się do orzecznictwa Trybunału Konstytucyjnego podkreślono, że konstytucyjne prawo zaskarżania orzeczeń i decyzji wydanych w I instancji stanowi istotny czynnik urzeczywistniania tzw. sprawiedliwości proceduralnej, która to zasada wynika nie tylko z art. 45 ust. 1 Konstytucji, ale także z art. 2 ustawy zasadniczej, i jest „wartością samą w sobie” 40 . W konsekwencji ograniczenie przez sąd kontroli jedynie do postanowienia Szefa KAS przedłużającego blokadę rachunku bankowego wobec braku możliwości zainicjowania przez podatnika instancyjnej kontroli rozstrzygnięcia Szefa KAS dotyczącego blokady na 72 godziny narusza, w ocenie NSA, przywołane konstytucyjne zasady. W tej sytuacji, skoro przedmiotem skargi jest postanowienie o przedłużeniu blokady rachunku bankowego, ocenie sądowej nie podlega tylko spełnienie przesłanek takiego przedłużenia, tzn. istnienia obawy, że podmiot kwalifikowany nie wykona istniejącego lub mającego powstać zobowiązania podatkowego, przekraczającego 10000 euro. Ocenie tej podlega również to, czy rachunek podatnika jest wykorzystywany do celów mających związek z wyłudzeniami lub zmierzającymi do wyłudzenia podatku (przesłanki blokady krótkiej).

Specyfika postępowania w przedmiocie blokady rachunku i jej przedłużenia nie zwalnia ani sądu, ani Szefa KAS, którzy ją stosują, od skrupulatnego i szczegółowego badania nie tylko tego, czy spełnione zostały w stanie faktycznym sprawy przesłanki ustawowe jej dokonania, ale też wysokości kwoty, jaką obejmuje przedłużenie blokady rachunku. Nie ulega wątpliwości, że postępowanie to ingeruje istotnie w sferę praw podatnika i może być dla niego środkiem wyjątkowo dolegliwym. Należy zwrócić uwagę, że przepisy Ordynacji podatkowej przewidują możliwość zwolnienia zablokowanych

39 Konstytucja Rzeczypospolitej Polskiej z dnia 2 kwietnia 1997 r. (Dz.U. z 1997 r., Nr 78, poz. 483 ze zm.), dalej: Konstytucja RP.

40 Wyroki TK z dnia: 16 listopada 1999 r., sygn. SK 11/99, OTK ZU nr 7/1999, poz. 158; 2 października 2006 r., sygn. SK 34/06, OTK ZU nr 9/A/2006, poz. 118; 27 marca 2007 r., sygn. SK 3/05, OTK ZU nr 3/A/2007, poz. 32. 
środków na wniosek podmiotu kwalifikowanego w enumeratywnie wskazanych przypadkach wymienionych w art. 119zy i $119 \mathrm{zz}$ o.p., nie zmienia to jednak faktu, że zastosowanie tego narzędzia uniemożliwia dysponowanie środkami zgromadzonymi na rachunku, co w znaczny sposób wpływa na możliwość prowadzenia działalności gospodarczej, podobnie jak zastosowanie instytucji zabezpieczenia zobowiązań podatkowych na podstawie art. 33 o.p. umożliwia organom dokonanie ingerencji w prawo własności podatnika, polegającej m.in. na czasowym ograniczeniu możliwości dysponowania zajętym składnikiem majątkowym oraz zmniejszeniu zdolności operacyjnej i kredytowej. W świetle orzecznictwa Trybunału Konstytucyjnego ochrona praw majątkowych nie oznacza zupełnej niemożliwości ingerencji państwa w ich treść, ich absolutnej nienaruszalności. Ingerencja taka może być uznana za dopuszczalną, a nawet - celową. Konieczne jest jednak zachowanie ram konstytucyjnych wyznaczających granice dopuszczalnych ograniczeń ochrony prawa majątkowego ${ }^{41}$.

Zagadnienie zapewnienia możliwie najskuteczniejszej ochrony interesów budżetu (Skarbu Państwa), której celem jest z pewnością omawiana regulacja w zakresie blokady rachunku bankowego i jej przedłużenia, doczekało się bogatego orzecznictwa na gruncie wykładni innego przepisu, tj. art. 87 ust. 2 u.p.t.u. Podkreślono, że przepis ten powinien być traktowany jako jeden $\mathrm{z}$ instrumentów równoważenia praw podatnika i interesów Skarbu Państwa. Środki te nie mogą być stosowane w taki sposób, który prowadziłby do systematycznego podważania prawa do odliczenia podatku, które to prawo jest fundamentalną zasadą wspólnego systemu VAT. Sprzeczne byłoby to bowiem z zasadą proporcjonalności. Stosowanie odpowiednich przepisów w tym zakresie wymaga zweryfikowania nie tylko tego, czy są one stosowane w celu zapewnienia możliwie najskuteczniejszej ochrony interesów budżetu (Skarbu Państwa), ale także czy ich zastosowanie nie przekracza konieczności osiągnięcia tego celu (ochrony interesów budżetowych) ${ }^{42}$.

Kolejnym ważnym zagadnieniem rozstrzyganym przez sądy administracyjne było wyjaśnienie przesłanki tzw. długiej blokady rachunku bankowego, tj. „uzasadniona obawa, że podmiot kwalifikowany nie wykona istniejącego lub mającego powstać zobowiązania podatkowego", o której

41 Wyroki TK z dnia: 22 czerwca 1999 r., sygn. K 5/99, OTK ZU nr 1/2000, poz. 3; 12 stycznia 2000 r., sygn. P 11/98, OTK ZU nr 5/1999, poz. 100.

${ }^{42}$ Wyrok TK z 13 października 2008 r., sygn. K 16/07, OTK-A 2008, nr 8/2008, poz. 136. 
mowa w art. $119 \mathrm{zw} \$ 1$ o.p. W ocenie NSA przesłanka ta powinna być analizowana przez organ podatkowy na gruncie konkretnych okoliczności faktycznych, nie tylko pod kątem zasad praworządności i powszechności opodatkowania (art. 83-84 Konstytucji RP), ale również z uwzględnieniem zasady zaufania (art. 2 Konstytucji RP, art. $121 \$ 1$ o.p.), która w demokratycznym państwie prawnym oznacza m.in., że postępowanie powinno być prowadzone w zaufaniu do podatnika ${ }^{43}$. Zaakceptowano jednocześnie pogląd, że przy dokonywaniu oceny, czy zachodzi uzasadniona obawa, że podmiot kwalifikowany nie wykona zobowiązania, ze względu na użycie w art. 119zw $\$ 1$ takiej samej przesłanki co w art. $33 \$ 1$ o.p., stosowanie tego przepisu powinno być zbliżone do zabezpieczenia zobowiązań podatkowych. Nie istnieje wyczerpujący katalog okoliczności, które mają znaczenie dla oceny, czy spełnione zostały przesłanki dokonania przedłużenia blokady. W każdej bowiem sprawie inne okoliczności mogą świadczyć o istnieniu obawy niewykonania zobowiązania ${ }^{44}$. Z tego też względu, w ocenie NSA, szczególnego znaczenia nabierało respektowanie przez organ podatkowy zasad postępowania dowodowego ${ }^{45}$. Wyjaśniono, że specyfika postępowania prowadzonego w przedmiocie blokady rachunku i jego przedłużenia, co do zasady, nie wyklucza stosowania przepisów zawartych w dziale IV Ordynacji podatkowej regulujących postępowanie dowodowe. $\mathrm{Z}$ art. 119zzb $\$ 4$ o.p. wynika, że w zakresie nieuregulowanym do postępowań dotyczących blokady rachunku podmiotu kwalifikowanego stosuje się odpowiednio przepisy działu IV. Działający w sprawie Szef KAS, wydając postanowienie, winien zatem pogodzić krótki czas prowadzonego w tym zakresie postępowania z przestrzeganiem obowiązku odpowiedniego stosowania reguł prowadzenia postępowania i przepisów te zasady precyzujących. Odpowiednie stosowanie oznacza bowiem, że normy prawne wyrażone w przepisach odesłanych mogą być interpretowane w kontekście odesłania szerzej albo węziej, bądź też mogą w ogóle nie znaleźć zastosowania, jeżeli jest to uzasadnione charakterem przepisu odsyłającego. Ze względu na swoją specyfikę - uzasadnioną celem zakładającym ograniczenie luki w podatku VAT spowodowanej wyłudzeniami

${ }^{43}$ Wyrok NSA z 27 kwietnia 2020 r, sygn. I FSK 335/20.

${ }_{44}$ Zob. M. Niezgódka-Medek, S. Babiarz i in., Ordynacja podatkowa. Komentarz, wyd. 11, Warszawa 2019.

45 Wyroki NSA z dnia: 3 marca 2020 r., sygn. I FSK 1425/19 i sygn. I FSK 1888/19; z 4 grudnia 2020 r., sygn. I FSK 1258/20 i sygn. I FSK 1326/20; wszystkie wyroki opublikowano w CBOSA. 
oraz eliminowaniem z obrotu gospodarczego firm oszukujących uczciwych przedsiębiorców - postępowanie w przedmiocie blokady rachunku bankowego jest ograniczone do bardzo krótkiego czasu, co w istocie musi się przekładać na realizację zasad postępowania.

\section{RAPORTOWANIE O SCHEMATACH PODATKOWYCH (MDR)} - PRZEPISY PODATKOWE PODLEGAJĄCE PROCEDUROM INTERPRETACJI INDYWIDUALNYCH NA WNIOSEK ZAINTERESOWANEGO

Regulacje dotyczące obowiązku raportowania o schematach podatkowych wprowadzone zostały w rozdziale 11a działu III Ordynacji podatkowej, który to rozdział dodano nowelą z 23 października 2018 r. Przepisy omawianego rozdziału (art. 86a-86o o.p.) wprowadziły do przepisów ogólnego prawa podatkowego nową instytucję - obowiązkowego ujawniania informacji o schematach podatkowych (ang. Mandatory Disclosure Rules - MDR), m.in. poprzez częściową transpozycję Dyrektywy Rady (UE) 2018/822 z dnia 25 maja 2018 r. zmieniającej dyrektywę 2011/16/UE w zakresie obowiązkowej automatycznej wymiany informacji w dziedzinie opodatkowania w odniesieniu do podlegających zgłoszeniu uzgodnień transgranicznych ${ }^{46}$ (dalej: Dyrektywa). Uzasadniając potrzebę tego rodzaju regulacji, wyjaśniono, że polska administracja skarbowa potrzebuje szybkiego dostępu do istotnych informacji dotyczących podejmowanych przez podatników działań w obszarze potencjalnie agresywnego planowania podatkowego. Tego rodzaju informacje są niezbędne w celu zidentyfikowania zagrożeń w obrębie prawa podatkowego, jakie stwarzają schematy podatkowe, i podjęcia stosownych działań. Dostęp do właściwych informacji już na etapie opracowania schematów pozwala na poprawę szybkości reagowania i podejmowania kroków legislacyjnych lub regulacyjnych, w tym na skuteczniejszą ocenę ryzyka podatkowego i lepsze wykorzystanie przez administrację skarbową zasobów w celu ochrony podatkowych dochodów budżetu państwa ${ }^{47}$.

Oprócz obowiązku transpozycji przepisów Dyrektywy do polskiego porządku prawnego istotnym argumentem na rzecz wprowadzenia obowiązku raportowania schematów podatkowych i nałożenia obowiązku przekazywania informacji o tych schematach na podmioty, które zawodowo zajmują się

\footnotetext{
46 Dz. Urz. UE L 139/1 z dnia 5 czerwca 2018 r.

47 Rządowy projekt ustawy, druk sejmowy 2860/VIII kadencja.
} 
przygotowywaniem, oferowaniem i wdrażaniem dla swoich klientów tych schematów, są wnioski z analizy dotychczasowej praktyki w tym obszarze. Schemat podatkowy może być pewnym rozwiązaniem intelektualnym, wypracowanym na podstawie znajomości przepisów prawa podatkowego i praktyki jego stosowania. W polskim systemie podatkowym nie istniał do 1 stycznia 2019 r. obowiązek ujawniania informacji o schematach podatkowych, umożliwiających administracji podatkowej pozyskiwanie informacji w drodze dobrowolnego czy też obowiązkowego ich przekazywania przez podmioty opracowujące bądź stosujące takie schematy. Dostępność tego rodzaju informacji jest niezbędna dla szybkiego określenia przez administrację skarbową obszarów polityki podatkowej i dochodów, w których poprzez stosowanie schematów podatkowych podatnicy uzyskują nieuzasadnione korzyści podatkowe. W bardzo dużym uproszczeniu: schemat podatkowy jest sposobem na osiągnięcie korzyści podatkowych, a obowiązek ujawniania administracji podatkowej informacji o schematach podatkowych stanowi zupełnie nową konstrukcję, nieznaną i niestosowaną wcześniej w polskim porządku prawnym. Celem wprowadzanej regulacji jest pozyskanie przez administrację skarbową wiedzy o stosowanych schematach podatkowych. Po dokonaniu zgłoszenia Szef KAS nadaje numer schematu podatkowego (NSP) i przekazuje zgłaszającemu drogą elektroniczną potwierdzenie jego nadania, zawierające informację o tym numerze i dane zawarte w przekazanej przez zgłaszającego informacji o schemacie podatkowym. Szef KAS ma również możliwość zwrócenia się do przekazującego informacje o ich uzupełnienie lub wyjaśnienie wątpliwości co do ich treści. Szef KAS odmówi nadania NSP, jeżeli przekazana informacja o schemacie podatkowym nie spełnia wymogów prawnych określonych dla tego rodzaju informacji. Ponadto NSP może zostać unieważniony, jeżeli okaże się, że NSP nadano wielokrotnie temu samemu schematowi podatkowemu lub nadano NSP na podstawie fałszywych lub fikcyjnych danych ${ }^{48}$.

Istotne jest, że przepisy te wprowadzają wiele nieznanych dotychczas obowiązków formalnych, obarczonych wysokimi sankcjami. Duża część z tych zobowiązań będzie spoczywać na podmiotach profesjonalnych, takich jak doradcy podatkowi, banki czy zawodowi pełnomocnicy. Niemniej jednak to podatnik musi cały czas być świadomy, że prowadzone przez niego działania mogą podlegać powinności raportowania i nie zawsze te

48 Wyroki WSA w Warszawie z dnia 21 kwietnia 2020 r., sygn. III SA/Wa 165/20 i sygn. III SA/Wa 167/20 (prawomocne); oba wyroki opublikowano w CBOSA. 
obowiązki zostaną wypełnione za niego. Biorąc pod uwagę, iż brzmienie nowych regulacji jest dosyć skomplikowane i zawierają one dużo definicji i pojęć nieznanych do tej pory polskim przepisom podatkowym, można mieć obawy, że ich interpretacja i stosowanie sprawi liczne trudności. Biorąc pod uwagę treść nowych regulacji, wszelkie działania zarówno restrukturyzacyjne, jak i polegające na zmianach struktury właścicielskiej oraz portfela aktywów powinny być każdorazowo wnikliwie analizowane pod kątem obowiązków raportowania przez promotorów, wspomagających oraz samych podatników. Podmioty wskazane w nowych przepisach powinny przystąpić do opracowania wewnętrznych procedur, które pozwolą im na wykonanie obowiązków oraz uchronią przed karami i innymi negatywnymi skutkami proponowanych zmian. W zakresie raportowania przez podmioty profesjonalne istotnym zagadnieniem jest $\mathrm{z}$ kolei to, że obowiązek ten nałożony został na osoby wykonujące zawody zaufania publicznego (doradca podatkowy, adwokat, radca prawny, notariusz czy biegły rewident). Podmioty te obowiązane są do zachowania w tajemnicy wszystkich informacji i dokumentów związanych z wykonywaniem zawodu. Obowiązek zachowania tajemnicy zawodowej nie jest ograniczony w czasie ${ }^{49}$. W tym celu dokonano odpowiednich zmian w przepisach regulujących wykonywanie tych zawodów i stwierdzono, że obowiązek zachowania tajemnicy zawodowej nie dotyczy m.in. informacji ,przekazywanych na podstawie przepisów rozdziału 11a działu III ustawy z dnia 29 sierpnia 1997 r. - Ordynacja podatkowa (Dz.U. z 2018 r., poz. 800, ze zm.) w zakresie określonym tymi przepisami”. Od strony formalnej zostały zatem stworzone podstawy prawne do zwolnienia wykonujących zawody zaufania publicznego od obowiązku dochowania tajemnicy zawodowej. Regulacja ta od samego początku wywołuje jednak wiele kontrowersji ze względu na podważanie jej zgodności z Konstytucją RP ${ }^{50}$.

49 Zob. art. 37 Ustawy z dnia 5 lipca 1996 r. o doradztwie podatkowym (tekst jedn. Dz.U. z 2016 r., poz. 794 ze zm.); art. 6 Ustawy z dnia 26 maja 1982 r. - Prawo o adwokaturze (tekst jedn. Dz.U. z 2016 r., poz. 1999 ze zm.); art. 3 Ustawy z dnia 6 lipca 1982 r. o radcach prawnych (tekst jedn. Dz.U. z 2016 r., poz. 233 ze zm.); art. 18 Ustawy z dnia 14 lutego 1991 r. - Prawo o notariacie (tekst jedn. Dz.U. z 2016 r., poz. 1796 ze zm.); art. 78 ust. 1 Ustawy z dnia 11 maja 2017 r. o biegłych rewidentach, firmach audytorskich oraz nadzorze publicznym (Dz.U. poz. 1089 ze zm.).

50 Zob. przyjęta do rozpoznania przez Trybunał Konstytucyjny skarga konstytucyjna (sygn. K 13/20) skierowana przez Krajową Izbę Doradców Podatkowych. 
Ponadto implementując przepisy o MDR, zdecydowano się na rozszerzenie zakresu stosowania tych przepisów. Dyrektywa nakłada obowiązek ujawniania informacji o schematach podatkowych występujących tylko w transakcjach transgranicznych. Tymczasem przepisy Ordynacji podatkowej wyraźnie wskazują, że obowiązek ten będzie dotyczył również transakcji krajowych, w przypadku gdy spełnione zostanie kryterium kwalifikowanego korzystającego (tj. gdy korzystającym będzie podmiot o przychodach bądź kosztach lub wartości aktywów przekraczającej równowartość $10 \mathrm{mln}$ euro, bądź też jeśli przedmiotem uzgodnienia będą rzeczy lub prawa o wartość rynkowej przekraczającej 2,5 mln euro). Zakresem polskich regulacji został też objęty podatek VAT, w części dotyczącej rozliczania nadwyżek VAT. Należy także podkreślić, że obowiązek raportowania wynikający zarówno z przepisów Dyrektywy, jak i z przepisów polskiej ustawy nie został wprost powiązany z możliwością wykorzystania danego schematu do agresywnej optymalizacji podatkowej. W konsekwencji raportowaniu podlegają wszystkie schematy podatkowe spełniające określone w ustawie cechy rozpoznawcze i ewentualne dodatkowe kryteria.

Na obecnym etapie stosowania tych przepisów w orzecznictwie sądowym rozstrzygnięcia doczekała się jedynie kwestia dopuszczalności objęcia ich zakresem indywidualnych interpretacji podatkowych (art. 14b o.p.). W ocenie NSA obowiązki prawnopodatkowe wynikające z działu III rozdziału 11a Ordynacji podatkowej, tj. związane z tzw. obowiązkiem raportowania schematów podatkowych, objęte są zakresem postępowania interpretacyjnego na podstawie art. $14 \mathrm{~b}$ i n. tej ustawy ${ }^{51}$. Wyjaśniono, że przepisy działu III rozdziału 11a Ordynacji podatkowej nie mają jednolitego charakteru. Jest to niejednorodny zbiór norm prawnych, wśród których można wskazać zarówno przepisy materialne, jak i procesowe, $\mathrm{w}$ tym takie, które objęte są katalogiem wyłączeń z art. 14b $\$ 2$ a o.p., w szczególności „regulujące właściwość, uprawnienia i obowiązki organów podatkowych” (np. art. 86h i n. o.p.). Natomiast, zwłaszcza w odniesieniu do obowiązku złożenia informacji o schemacie podatkowym, przepisy te należy uznać za regulacje materialnoprawne podlegające interpretacji Dyrektora Krajowej Informacji Skarbowej ${ }^{52}$ Z powyższym wiąże się drugi argument natury systematycznej (a rubrica), wskazujący na zamieszczenie regulacji dotyczących

51 Wyrok NSA z dnia 28 stycznia 2021 r., sygn. I FSK 1703/20, CBOSA.

${ }_{52}$ Zob. W. Podsiadło, Przepisy dotyczace schematów podatkowych a możliwość wydania indywidualnej interpretacji przepisów prawa podatkowego, „Przegląd Podatkowy” 2020, nr 10, s. 42-46. 
raportowania schematów podatkowych w dziale III Ordynacji podatkowej (rozdział 11a), poświęconym zobowiązaniom podatkowym, tj. tym dziale, który ma charakter konstytucyjny $\mathrm{z}$ perspektywy systemu prawa podatkowego, i odnosi się do ogólnych zagadnień materialnego prawa podatkowego, wiążących się zwłaszcza z powstawaniem, regulowaniem i wygasaniem zobowiązań podatkowych oraz odpowiedzialnością podatkową za owe zobowiązania. Udzielenie interpretacji indywidualnej w zakresie MDR ma znaczenie, w aspekcie jej funkcji ochronnej, już tylko z perspektywy obowiązujących regulacji karnoskarbowych. Ochrona wnioskodawcy przejawia się tu w braku możliwości wymierzenia sankcji na gruncie prawa karnego skarbowego (art. 14k $\$ 3$ o.p.). Ponadto, uwzględniając zasadnicze kwestie, takie jak ratio legis instytucji interpretacji przepisów prawa podatkowego jako tej, która ma zapewniać ochronę podatnika, w tym zwłaszcza bezpieczeństwo prawne $\mathrm{w}$ ramach skomplikowanego systemu prawa podatkowego (art. 2 Konstytucji RP), nie sposób zawężająco interpretować zakresu stosowania przedmiotowej instytucji. W szczególności niedopuszczalne jest ograniczanie zakresu jej zastosowania (tj. uprawnień podatnika) w sposób dorozumiany, bez wyraźnej wypowiedzi ustawodawcy, bądź też w drodze złożonych argumentów konstrukcyjnych i systemowych.

Kolejne sprawy z tego zakresu, w których organ interpretacyjny odmówił wydania interpretacji, czekają dopiero na rozpoznanie przez Naczelny Sąd Administracyjny ${ }^{53}$.

\section{Podsumowanie - ROla SĄDOWNiCtWA Administracyjnego W ZAPEWNIENIU RÓWNOWAŻENIA RÓŻNYCH INTERESÓW STRON POBORU PODATKÓW}

Klauzula przeciwko unikaniu opodatkowania, regulacje związane z blokadą rachunku podatkowego podmiotu kwalifikowanego, obowiązek raportowania schematów podatkowych są normami ingerencyjnymi, o znacznym stopniu dolegliwości dla ich adresatów. Wymagały więc obudowania instytucjami, które ów rygoryzm czynią możliwie mało dolegliwym dla tych podatników, którzy nie wykazują szczególnej determinacji w podejmowaniu

${ }^{53} \mathrm{Na}$ przykład skargi kasacyjne od wyroków WSA z dnia: 30 września 2020 r., sygn. I SA/Bk 556/20 (w NSA III FSK 2931/21); 24 lipca 2020 r., sygn. I SA/Po 52/20 (w NSA III FSK 2668/21); 10 lipca 2020 r., sygn. I SA/Lu 714/19 (w NSA III FSK 3131/21); 24 czerwca 2020 r., sygn. III SA/Wa 512/20 (w NSA II FSK 2386/20); 22 maja 2020 r., sygn. III SA/Wa 445/20 (w NSA III FSK 2498/21). 
działań zasługujących na negatywną normatywną reakcję państwa. Stosowanie tych instrumentów wymaga szczególnej ostrożności, starannego zbalansowania ochrony interesów państwa i ochrony interesów obywateli narażonych na jego dotkliwą w skutkach ingerencję. Konstruując tak dolegliwe dla podatników normy, ustawodawca powinien zachować szczególną wstrzemięźliwość. Poziom ochrony interesów państwa, obywateli i uczestników obrotu gospodarczego wymaga pieczołowitego wyważenia. Prawodawca powinien zdawać sobie sprawę, że tego rodzaju rozwiązania mają charakter wyjątkowy. Rozwiązania takie nie powinny być wykorzystywane do zwalczania zjawisk, których patologiczny rezultat nie może być uznany za wyjątkowo groźny. Ciężar gatunkowy negatywnych zjawisk powinien pozostawać $\mathrm{w}$ odpowiedniej proporcji do charakteru środków, jakimi są zwalczane. Ich stosowanie powinno być zastrzeżone dla przypadków, w których rozmiar patologicznych skutków usprawiedliwia charakter prawnej reakcji na nie. Tego rodzaju refleksji jednak zabrakło. W odniesieniu do klauzuli dokonano wręcz zaostrzenia jej przepisów i zrezygnowano z rozwiązań wyłączających jej zastosowanie w zależności od rozmiaru korzyści podatkowych.

Przyjmuje się, że konstytucyjne prawo do sądu obejmuje zarówno prawo do wymiaru sprawiedliwości, czyli merytorycznego rozstrzygnięcia w sprawach z zakresu praw jednostki, jak i prawo do sądowej kontroli aktów, które godzą w konstytucyjne prawa i wolności jednostki. W tym ostatnim przypadku sąd realizuje czynności z zakresu ochrony prawnej, chroniąc jednostkę przed arbitralnością działań podmiotu sprawującego władztwo publiczne. Prawo do sądu oznacza dla ustawodawcy obowiązek ustanowienia regulacji prawnej, która zapewni rozpatrzenie sprawy przez sąd, na żądanie zainteresowanego. Odwołując się do orzecznictwa TK, podkreślono, że konstytucyjne prawo zaskarżania orzeczeń i decyzji wydanych w I instancji stanowi istotny czynnik urzeczywistniania tzw. sprawiedliwości proceduralnej, która to zasada wynika nie tylko z art. 45 ust. 1 Konstytucji RP, ale także z art. 2 tego aktu, i jest „wartością samą w sobie”

Określone w ten sposób kompetencje ustrojowe sądów administracyjnych nabierają szczególnego znaczenia $\mathrm{w}$ odniesieniu do wprowadzonych różnego rodzaju niestandardowych, odbiegających od klasycznych procedur podatkowych, rozstrzygnięć organów administracji wydawanych w ramach

${ }^{54}$ Wyroki TK z dnia: 16 listopada 1999 r., sygn. SK 11/99, OTK ZU nr 7/1999, poz. 158; 2 października 2006 r., sygn. SK 34/06, OTK ZU nr 9/A/2006, poz. 118; 27 marca 2007 r., sygn. SK 3/05, OTK ZU nr 3/A/2007, poz. 32. 
procedur uszczelniających system podatkowy. Oznacza to, podobnie jak w odniesieniu do sądowej kontroli interpretacji indywidualnych prawa podatkowego wydawanych na podstawie art. $14 \mathrm{~b} \$ 1$ o.p., konieczność ukształtowania praktyki orzeczniczej sądów administracyjnych. Zgodnie $\mathrm{z}$ aktualnymi poglądami orzecznictwa ukształtowany w tych przepisach charakter prawny czynności organów podatkowych, polegających na informowaniu „o zakresie stosowania prawa”, nie może prowadzić ani do wykreowania bądź skonkretyzowania obowiązku, ani też do jego zniesienia bądź ograniczenia. $Z$ tego względu indywidualna interpretacja oraz poprzedzające jej wydanie postępowanie znacznie odbiegają od postępowania podatkowego, w którym następuje określenie lub ustalenie zobowiązania podatkowego. W zasadzie nie ma tu postępowania dowodowego, a wydane „rozstrzygnięcie” zbliżone jest raczej do swego rodzaju opinii prawnej, oceniającej przedstawione zdarzenie faktyczne (istniejące lub przyszłe), czy też rozwiązania kazusu z zakresu prawa podatkowego, niż do aktu administracyjnego, władczo rozstrzygającego o podatkowych prawach lub obowiązkach danego podmiotu ${ }^{55}$.

Jak dowodzi analiza dotychczasowego orzecznictwa sądów administracyjnych, na tle stosowania wybranych instrumentów uszczelniających pobór podatków w Polsce przesłanki ich zastosowania powinny każdorazowo być rozpatrywane na gruncie konkretnych okoliczności faktycznych, nie tylko pod kątem zasad praworządności i powszechności opodatkowania (art. 83-84 Konstytucji RP), ale również z uwzględnieniem zasady zaufania (art. 2 Konstytucji RP, art. $121 \$ 1$ o.p.), która w demokratycznym państwie prawnym oznacza m.in., że postępowanie powinno być prowadzone w zaufaniu do podatnika. W orzecznictwie podkreślono też, że przy wprowadzaniu tego rodzaju rozwiązań dolegliwych dla podatników w sposób szczególny należało respektować zasadę proporcjonalności przy tworzeniu prawa. Zasada ta kładzie szczególny nacisk na adekwatność celu i środka użytego do jego osiągnięcia. Znaczy to, że spośród możliwych środków oddziaływania należałoby wybierać środki skuteczne dla osiągnięcia założonych celów, a zarazem jak najmniej uciążliwe dla podmiotów, wobec których mają być zastosowane, lub dolegliwe w stopniu nie większym, niż jest to niezbędne dla osiągnięcia założonego celu.

55 Wyrok TK z dnia 25 września 2014 r., sygn. K 49/12, OTK-A 2014, nr 8, poz. 94; postanowienie sygnalizacyjne TK z dnia 29 października 2014 r., sygn. S 5/14; uchwała NSA z dnia 8 stycznia 2007 r., sygn. I FPS 1/06, ONSAiWSA 2007, nr 2, poz. 27. 
Tego typu podejście interpretacyjne nabiera szczególnego znaczenia wobec wprowadzenia tych rozwiązań w oderwaniu od rozwiązań prawnych tworzących gwarancje dla podatników. Rozwiązania mające takie znaczenie prawne zawarte były w projekcie nowej Ordynacji podatkowej chociażby w postaci przewidzianego w niej katalogu zasad ogólnych prawa podatkowego ${ }^{56}$. Nie wzięto pod uwagę i nie rozważono wszystkich propozycji przedstawianych w tym zakresie w toku prac Komisji Kodyfikacyjnej Ogólnego Prawa Podatkowego, jak normatywne określenie katalogu praw i obowiązków podatników, zasady ogólne prawa podatkowego - zakaz nadużywania praw przez organy podatkowe, domniemanie rzetelności zobowiązanego, ochrona uzasadnionych oczekiwań ${ }^{57}$. Rozwiązaniem wymagającym rozważenia było także ustawowe wprowadzenie Karty Praw Podatnika $^{58}$. Do uchwalenia tych, tak ważnych z punktu widzenia ochrony praw podatnika, przepisów jednak ostatecznie nie doszło. W efekcie mamy nagromadzenie, może i słusznych kierunkowo, rozwiązań dyscyplinujących podatników, z niewystarczającymi dla ich ochrony zasadami ogólnymi postępowania podatkowego, oraz odosobnioną zasadę ogólną prawa podatkowego o rozstrzyganiu wątpliwości na korzyść podatnika (art. 2a o.p.). Należy również brać pod uwagę to, że większość rozwiązań uszczelniających system podatkowy stosowana jest poza klasycznym postępowaniem podatkowym, w związku z czym stosowanie reguł właściwych dla tego postępowania a wzmacniających pozycję podatnika wymaga zabiegów interpretacyjnych.

Wykazywany pośpiech we wprowadzaniu zmian uszczelniających system podatkowy oraz dość przypadkowe ich umieszczenie w ustawie Ordynacja podatkowa mają swoje konsekwencje dla sądowej kontroli wydawanych na podstawie tych przepisów indywidualnych rozstrzygnięć. Jak się okazuje, część z tych rozwiązań wprost nie respektowała zasad konstytucyjnych (np. pozbawienie prawa do zaskarżenia blokady krótkiej STIR). Oznaczało to konieczność wypracowania właściwych reguł sądowej kontroli

${ }^{56}$ Zob. B. Brzeziński, W. Nykiel, Zasady ogólne prawa podatkowego, [w:] Prawo podatkowe. Teoria. Instytucje. Funkcjonowanie, red. B. Brzeziński, W. Nykiel, Toruń 2009, s. 136-137; Rządowy projekt ustawy - Ordynacja podatkowa, druk sejmowy nr 3517/VIII kadencja.

57 Zob. L. Etel, Nowa Ordynacja Podatkowa - z prac Komisji Kodyfikacyjnej Ogólnego Prawa Podatkowego, Białystok 2017.

${ }^{58}$ Poselski projekt ustawy - Karta Praw Podatnika, druk sejmowy nr 3458/VIII kadencja. 
dla każdego z tych instrumentów, respektujących kontekst ich wprowadzenia, oraz reguł konstytucyjnych tworzenia prawa. Jest to jednak dopiero początek drogi wobec ciągle napływających do sądów administracyjnych nowych spraw indywidualnych podatników, kwestionujących wydane na podstawie tych przepisów rozstrzygnięcia. Do najczęściej podnoszonych zarzutów należy nierespektowanie zasad konstytucyjnych przy tworzeniu i stosowaniu prawa oraz nierespektowanie konstytucyjnie gwarantowanych praw podatnika.

\section{BiBLIOGRAFIA}

Brzeziński B., Nykiel W., Zasady ogólne prawa podatkowego, [w:] Prawo podatkowe. Teoria. Instytucje. Funkcjonowanie, red. B. Brzeziński, W. Nykiel, Toruń 2009.

Etel L., Nowa Ordynacja podatkowa - z prac Komisji Kodyfikacyjnej Ogólnego Prawa Podatkowego, Białystok 2017.

Gajewski D., Wplyw wybranych instrumentów prawnopodatkowych na politykę optymalizacji opodatkowania holdingów międzynarodowych, Warszawa 2012.

Litwińczuk H., Prawo podatkowe przedsiębiorców, Warszawa 2003.

Mastalski R., Glosa do wyroku NSA z 1 grudnia 2011 r., I FSK 1565/11, „Orzecznictwo Sądów Polskich" 2012, nr 12, s. 119.

Niezgódka-Medek M., Babiarz S. i in., Ordynacja podatkowa. Komentarz, wyd. 11, Warszawa 2019.

Olesińska A., Klauzula ogólna przeciwko unikaniu opodatkowania, Toruń 2013.

Podsiadło W., Przepisy dotyczace schematów podatkowych a możliwość wydania indywidualnej interpretacji przepisów prawa podatkowego, „Przegląd Podatkowy” 2020, nr 10.

Słownik języka polskiego, oprac. L. Drabik, A. Kubiak-Sokół, E. Sobol, L. Wiśniakowska, Warszawa 1996.

Szubiakowski M., Problemy proceduralne blokady rachunku bankowego w celu przeciwdziałania wyłudzeniom skarbowym, „Zeszyty Naukowe Sądownictwa Administracyjnego" 2018, nr 3(78).

\section{INSTRUMENTS SEALING THE TAX SYSTEM IN THE JURISPRUDENCE OF ADMINISTRATIVE COURTS}

Summary. Actions taken by taxpayers - including the entrepreneurs - aimed at minimizing tax burdens are common and, in a sense, understandable. For these reasons, changes introduced to the tax law should take into better account the emerging risks of tax evasion. There is no doubt that tax evasion is contrary to the objectives of taxation; therefore it should and can be counteracted. The level of difficulty of the process of sealing the tax system in such a way that the constitutional requirements are met and bearing in mind compliance with EU law as well as the principles of legislative technique, have been proven by the recently introduced legislative changes in this area. This has also been confirmed by the issues related to the application by the administrative courts of the most important (also for the entire tax collection system) solutions introduced to the Tax 
Ordinance. Such solutions are the following: general clause against tax avoidance, the IT System (or: the Communication System) of the Clearing House (Polish abbrev. STIR) and Mandatory Disclosure Rules (MDR). As demonstrated by the analysis of the previous jurisprudence of administrative courts in the light of the use of selected instruments sealing tax collection in Poland, the conditions for their application should be examined ad casum in the context of specific factual circumstances. They should be examined not solely in terms of the rule-of-law-principle and the universality of taxation (Art. 83-84 of the Polish Constitution), but also in terms of the principle of trust (Art. 2 of the Polish Constitution as well as art. $121 \S 1$ of the Tax Ordinance). The latter points out that the tax proceedings in a democratic state of law shall be conducted regarding the principle of trust in taxpayers. It has been also emphasized in the case-law, that the principle of proportionality had to be particularly respected when introducing this kind of the legal solutions highly intrusive for taxpayers.

Keywords: taxes, tax law, tax avoidance, tax evasion, general clause, bank account blocking, Mandatory Disclosure Rules, administrative court 